\title{
KARAKTERISTIK ISLAMIC BANKING DALAM HUKUM PERBANKAN INDONESIA
}

\author{
Muhammad Abdul Lathif \\ Program Magister Kenotariatan Fakultas Hukum Universitas Brawijaya \\ JI. MT. Haryono No 169; Malang; 65145; Indonesia;(0341) 553898 \\ muhammadabdlathif@yahoo.com
}

\begin{abstract}
The purpose of this study is to examine, describe and analyze holistically, comprehensively on the characteristics of Islamic Banking in Indonesian Banking Law. This research is normative juridical. The result of the research: Islamic banking has the main character that becomes the principle of Islamic Banking system in Indonesia that is the universal view that Islamic banking is applicable to every person regardless of religious difference and economic ability. Variations that the product varies from hajj and umrah savings, general savings, demand deposits, time deposits, profit sharing, buying, and selling. Facilitate that the acceptance and distribution of zakat, infaq, alms, wakaf of virtue fund have ATM facility, mobile banking, internet banking and interconnection among Islamic Banking. It is fair that Islamic banking gives something only to the right and treats something according to its portion. Maslahah Islamic banking is useful and brings virtue to all aspects of life. Transparent Islamic banking activities are very open to all people. as well as honest transactions in executing a contract/contract. Looking at some of these characteristics, we can understand that Islamic Banking in Indonesia already has a solid initial foundation as an implementation of the Islamic Economic Philosophy.
\end{abstract}

Keywords: Characteristics, Indonesian Banking Law,Islamic Banking.

\begin{abstract}
Abstrak
Tujuan dari penelitian ini adalah untuk untuk mengkaji, mendeskripsikan dan menganalisis secara holistik, komprehensifmengenai karakteristik Islamic Banking dalam Hukum Perbankan Indonesia.Penelitian ini bersifat yuridis normatif.Hasil penelitian: bahwa Perbankan Islammempunyai karakteristik utama yang menjadi prinsip sistem Perbankan Islam di Indonesia yaitu bersifat universal memandang bahwa Perbankan Islam berlaku untuk setiap orang tanpa memandang perbedaan agama dan kemampuan ekonomi. Variatif bahwa produk bervariasi mulai dari tabungan haji dan umrah, tabungan umum, giro, deposito, pembiayaan yang berbasis bagi hasil, jual beli dan sewa. Fasilitatif bahwa penerimaan dan penyaluran zakat, infak, sedekah, wakaf dana kebajikan memiliki fasilitas ATM, mobile banking, internet banking dan interkoneksi antar Perbankan Islam. Adil bahwa Perbankan Islam memberikan sesuatu hanya kepada yang berhak serta memperlakukan sesuatu sesuai dengan porsinya. Maslahah Perbankan Islam bermanfaat dan membawa kebajikan bagi seluruh aspek kehidupan. Transparan dalam kegiatanya Perbankan Islam sangat terbuka bagi seluruh masyarakat. serta transaksi yang jujur dalam menjalankan suatu kontrak/akad. Melihat beberapa karakteristik ini, kita bisa memahami bahwa Perbankan Islam di Indonesia sudah memiliki landasan awal yang kokoh sebagai implementasi dari Falsafah Ekonomi Syariah.
\end{abstract}

Kata Kunci: Hukum Perbankan Indonesia, Karakteristik,Perbankan Islam. 
Karakteristik Perbankan Islam di Indonesia, berbeda dengan sistem perbankan dalam model barat (konvensional). Sebelum membahas Perbankan Islam di Indonesia adalah sangat penting untuk melakukan kilas balik, bagaimana sistem perbankan dalam model Barat (konvensional) mulai dikenal dikalangan Muslim. Sejarah perbankan diseluruh penjuru dunia didominasi oleh sejarah industri perbankan Eropa. Meski di era kekaisaran Turki Usmani (Ottoman) sekalipun, dalam industri perbankan dibelahan dunia yang diluar kekuasaan Turki Usmani dominasi bank Eropa sangat kuat. Bank kekaisaran Turki Usmani dimiliki oleh Anglo-Perancis dan bank kekaisaran Persia tidak lain juga dimiliki oleh orang Inggris. Bahkan, sebagian besar lembaga financial intermediary (jasa keuangan) di wilayah Turki Usmani dikendalikan oleh orang-orang Yunani. Meskipun demikian, tidak berarti bahwa berbagai transaksi keuangan itu adalah hal yang sama sekali baru bagi orang Muslim, karena praktik seperti itu telah dilakukan sejak masa Rasulullah SAW., khususnya di Hijaz (Wilson, 1995).

Tahun 1920-an, dunia muslim mulai menyadari bahwa keberadaan lembaga jasa keuangan yang ada ternyata tidak mampu untuk memenuhi dan menjawab berbagai keperluan perkembangan dunia bisnis. Fakta ini memaksa untuk didirikanya berbagai bank di negara-negara Muslim. Bank Misr di Mesir, Bank Arab yang dimiliki oleh seorang warga negara palestina, dan bank Habib British India adalah beberapa contoh dari mulai didirikanya institusi perbankan dikalangan dunia Muslim. Saudi Arabia, yang menolak bank-bank tersebut dengan alasan imperialisme yang dilakukan terhadap Islam dan bersifat kebarat-baratan dan tidak Islami, pada periode berikutnya terutama setelah ditemukanya minyak, akhirnya mengakui perlunya bank dari Barat (Wilson, 1995).

Ide Perbankan Islam modern mulai ada pertengahan abad ke -20 M, tepatnya pada dekade 40-an (Saeed, 1996). Arti modern dan empirik, bank adalah badan usaha yang menghimpun dana dari masyarakat dalam bentuk simpanan dan menyalurkanya kepada masyarakat dalam bentuk kredit dan atau bentuk-bentuk lainya dalam rangka meningkatkan taraf hidup rakyat banyak. Pengertian bank menurut Pasal 1 Ayat 2 Undang-Undang Republik Indonesia Nomor 7 Tahun 1992 tentangPerbankan,bank merupakan financial intermediary antara pemilik modal dan pengguna modal. Sebagai financial intermediary, Perbankan Islam khususnya di Indonesia (Bank Indonesia, 1999). Bank juga melakukan berbagai usaha sekaligus pengembanganya dengan menawarkan bermacam produk baik itu yang berkategori penghimpunan dana, penyaluran dana, maupun jasa lainya berdasarkan prinsip Islam.

Menurut Gazette (2015) Saat ini Perbankan Islam telah menunjukkan perkembangan yang sangat berarti, bahkan hari ini Perbankan Islam diestimasi mengelola asset Perbankan Islam di seluruh dunia diperkirakan mengelola aset senilai US\$ 2.1 trilyundanIslamic Bangking US\$ 1.6 trilyun. Sebagai hasil dari pandangan yang berdasar pada keyakinan agama tersebut, Perbankan Islam menunjukkan kekhasanya yang sangat mencolok dalam hal relasi antara bank dengan nasabah. Perbankan Islam boleh jadi memiliki pengalaman relasi dengan nasabah dalam sebuah model yang berbeda jika dibandingkan dengan perbankan konvensional.

Hal ini tidak bermaksud untuk mengatakan bahwa faktor ekonomi tidak begitu penting, akan tetapi bagi nasabah yang beragama Islam, afiliasi mereka terhadap Perbankan Islam boleh jadi karena atas dasar keyakinan mereka atas sentimen agama. Ajaran Islam yang telah menetapkan bahwa riba adalah sesuatu yang harus dijauhi dan karenanya orang muslim dilarang untuk bertransaksi dalam hal keuangan yang mengandung unsur riba (Fatwa Majelis Ulama Indonesia Nomor 1 Tahun 2004). Jadi dalam tingkat tertentu, afiliasi nasabah muslim terhadap bank mungkin bukan semata- 
mata karena alasan ekonomi tetapi juga karena alasan ideologis.

Atas dasar kekhasan seperti diatas, adalah satu hal yang pasti bahwa terasosiasikanya Perbankan Islam dengan kata-kata Islam atau syariah adalah dikarenakan adanya kaitan yang erat antara aspek konseptual dan praktis dari bisnis perbankan ini dan prinsip-prinsip Islam atau syariah. Dengan kata lain, adalah selalu benar untuk dapat dikatakan bahwa salah satu aspek mendasar yang membedakan Perbankan Islam dan konvensional adalah kepatuhan pada prinsip syariah (shari'ah compliance).

Atas dasar itulah, maka cukup rasional untuk menyimpulkan bahwa salah satu diantara aspek hukum dalam Perbankan Islam adalah regulasi tentang kepatuhan syariah. Isu tentang kepatuhan syariah tampak semakin penting dalam situasi dimana Perbankan Islam selalu ditantang dengan permintaan dari nasabah agar bersifat inovatif dan berorientasi pada bisnis (misalnya dalam menawarkan instrumen dan produk baru), sebagaimana perbankan konvensional juga melakukan hal tersebut (Abdullah, 2003).

Fakta di atas dapat mendorong posisi Perbankan Islam ke tengah dari dua kekuatan pendorong. Disatu sisi, Perbankan Islam harus mengakomodasi tuntutan dari nasabah sebagaimana tersebut diatas yang boleh jadi bertententangan dengan prinsip syariah, tetapi disisi lain Perbankan Islam itu secara ketat terikat oleh apa yang dinamakan dengan kepatuhan syariah.

Sebagaimana respon dari tuntutan yang semacam itu, maka bisnis Perbankan Islam kemudian dilaksanakan dalam cara yang sedemikian rupa sehingga secara selintas tampak tidak jauh berbeda dengan bisnis perbankan konvensional. Imitasi dalam hal produk, penerapan kriteria konvensional dalam pengukuran profit dan kinerja, adalah beberapa contoh yang dapat disebutkan. Pertanyaan berkenaan dengan kepatuhan syariah yang berimplikasi dengan karakteristik Perbankan
Islam komitmen untuk menghindari riba dan gharar, keperluan untuk merubah mindset berbasis riba ke mindset yang bebas dari riba, kemudian muncul. Konteks seperti inilah, isu diseputas kepatuhan syariah dari Perbankan Islam penting untuk dicermati (Triyanta, 2016).

Jangka waktu sekitar 23 tahun perkembanganya, perkembangan Islam di Indonesia telah menunjukkan kesan yang mengagumkan. Meskipun total asetnya masih sangat rendah dibandingkan dengan perbankan konvensional, terdapat beberapa hal menarik dalam kinerja Perbankan Islam. Berdasarkan beberapa ukuran kinerja, hal ini membuktikan bahwa bisnis Perbankan Islam bergerak dalam arah positif.

Perhitungan yang dilakukan oleh Bank Indonesia, dalam jangka 17 tahun, yakni antara tahun 2000 sampai dengan munculnya Undang-Undang Republik Indonesia tentangPerbankan Syariah tahun 2008 saja, total aset industri Perbankan Syariah telah meningkat sebesar 27 kali lipat dari Rp 1,79 triliun pada tahun 2000, menjadi Rp 49,6 triliun pada akhir tahun 2008. Ini berarti, besaran pertumbuhan aset mencapai angka yang fantastis, yakni $46,3 \%$ pertahunya. Periode tertentu, bahkan melebihi dari laju pertumbuhan aset industri ini di wilayah regional (Asia Tenggara). dan sebagaimana disebutkan diatas, saat ini (awal 2015), aset dari Perbankan Syariah di Indonesia mencapai Rp 260,366 triliun rupiah (Triyanta, 2016).

Secara umum dapat dikatakan terdapat sebuah peningkatan yang signifikan terhadap total aset binis Perbankan Syariah di tahun dalam perkembanganya di Indonesia, jika dilihat dalam sudut periodisasi yang manapun. Profitability (tingkat keuntungan) dalam Perbankan Islam secara relatif adalah tinggi. Terdapat sejumlah perbaikan dalam keuntungan sebelum terkena pajak dan zakat yang dicatat oleh sektor Perbankan Islam.

Disamping itu, apabila menggunakan ukuran tingkat profitabilitas, aktivitas pembiayaan, non-performing financing ratio, liquidity, dan capital adequacy 
ratio (rasio kecukupan modal), dapat dikemukakan bahwa Perbankan Islam menunjukkan kinerja yang bagus. Desain pengembangan Perbankan Islam di Indonesia, Bank Indonesia melalui direktorat Perbankan Syariah, sudah menyiapkan sebuah blue print atau cetak biru dari pengembangan Perbankan Islam di Indonesia. Berdasarkan pada fakta dan pencapaian Perbankan Islam sampai dengan tahun 2002, prospek dimasa depan telah disusun dan langkah-langkah bertahap dari pengembangan juga telah direncanakan. Rencana ini terdiri atas tiga periode dari pencapaian secara bertahap untuk 10 tahun pengembanganya.

Tahap pertama adalah periode antara 20022004. Dimana periode ini ditujukan untuk mendapatkan sebuah dasar yang kokoh untuk pengembangan yang berkelanjutan. Tahap kedua adalah dari 2004-2008, dimana dalam periode ini ditujukan untuk memperkuat strktur industri perbankan. Tahap terakhir adalah dari 2008-2011 adalah untuk mematuhi berbagai standar internasional untuk produk keuangan dan jasa Perbankan Islam. Berdasarkan pada cetak biru ini, diharapkan pada tahun 2011 (Bank Indonesia, 2002). Perbankan Islam di Indonesia akan mampu menjadi sebuah pemain dalam percaturan Perbankan Islam di arena internasional. Namun, jika dilihat dari perjalanan perkembangan Perbankan Islam sampai dengan saat ini, apa yang dicanangkan dalam cetak biru tersebut belum dapat dicapai. Meski demikian, tahapan perkembangan yang ada sudah menunjukkan perkembangan yang sangat signifikan (Triyanta, 2016).

Menurut Ayub (2009), Adapun Perbankan dan keuangan Islami telah dipahami sebagai perbankan dan keuangan yang sesuai dengan etos dan sistem nilai Islam. Oleh sebab itu, ia diatur, disamping oleh Peraturan-peraturan pemerintahan yang baik dan manajemen risiko, oleh prinsip-prinsip yang ditentukan oleh Syariah Islam. Tahun 1980an, istilah "perbankan bebas bunga" digunakan untuk mendeskripsikan suatu sistem alternatif dari sistem konvensional yang berbasis bunga. Akan tetapi, istilah "perbankan bebas bunga" adalah konsep yang sempit, hanya mencakup beberapa instrumen perbankan atau kegiatan operasional yang menghindari bunga.

Perbankan Islami, dalam istilah yang lebih umum, diharapkan tidak hanya menghindari transaksi-transaksi yang berbasis bunga, tapi juga menghindari gharar, yang juga dilarang dalam syariah Islam, dan praktik-praktik lain yang tidak beretika serta berartisipasi dalam mencapai sasaran dan tujuan suatu perekonomian Islami.Sifat dasar bisnis tersebut di atas menandai filosofi dan karakteristik disiplin ilmu yang mulai berkembang di dunia perbankan tersebut. Selanjutnyaakan membahas karakteristik Islamic Banking dalam Hukum Perbankan Indonesia.

\section{Metode Penelitian}

Bertolak dari pemikiran dan pemahaman terhadap isu-isu hukum dalam mengetahui hukum perbankan Indonesia yang akan dijadikan suatu pedoman bagi bangsa Indonesia, khususnya dalam mengetahui dan menganalisis karakteristik pengaturan Islamic Banking dalam hukum perbankan Indonesia, maka pendekatan penelitian yang digunakan adalah pendekatan konseptual (conceptual approach), yaitu pendekatan melalui prinsipprinsip dan konsep-konsep yang dapat ditemukan dalam pandangan-pandangan sarjana ataupun doktrin-doktrin hukum (Marzuki, 2005). Berkenaan konsep-konsep yang kemukakan yakni mengenai pola hubungan antara negara dan konsep-konsep ajaran agama. dan pendekatan peraturan perundangundangan (statute approach), menurut Mahmud (2005).

Penelitian ini memfokuskan kepada UndangUndang Dasar Republik Indonesia Tahun 1945, Undang-Undang Republik Indonesia Nomor 10 Tahun 1998 tentang Perubahan Atas UndangUndang Republik Indonesia Nomor 7 Tahun 1992 
tentang Perbankan dan Undang-Undang Republik Indonesia Nomor 21 Tahun 2008 tentang Perbankan Syariah. Pemilihan Undang-Undang ini didasarkan pada sebuah kenyataan bahwa nilainilai yang terkandung didalamnya belum bisa menjiwai nilai-nilai ekonomi bangsa Indonesia yang masih ada ajaran kapitalis liberalis didalam subatansinya. Pendekatan perbandingan hukum (comparative approach), perbandingan disini dianggap perlu dan penting, dalam rangka memberikan obyektifitas kajian terhadap hukum perbankan Indonesia dan untuk mengetahui permasalahan hukum yang darinya dapat diharapkan menjadi masukan-masukan sebagai penyempurnaan atau pembangunan hukum Islamic banking di Indonesia.

Adapun bahan hukum dalam penelitian karya ilmiah ini dibagi kedalam tiga kategori anatara lainBahan Hukum PrimerterdiridariAl-Quran dan Al-Hadist; Undang-Undang Dasar Republik Indonesia Tahun 1945; Undang-Undang Republik Indonesia Nomor 10 Tahun 1998 tentang Perubahan Atas Undang-Undang Nomor 7 Tahun 1992 tentang Perbankan; dan Undang-Undang Republik Indonesia Nomor21 Tahun 2008 tentang Perbankan Syariah.

Analisa terhadap bahan hukum dalam penelitian ini ditujukan untuk memperoleh gambaran atau keadaan yang sebenarnya mengenai karakteristik pengaturan Islamic Banking dalam hukum perbankan Indonesia, khususnya terkait filosofis, politik, dan budaya bangsa Indonesia. Pemerintah yang bersinergitas dengan MUI (Majelis Ulama Indonesia) terkait kekuatan hukum fatwa DSNMUI, serta solusi pembangunan Islamic Law Banking di Indonesia agar dapat memberikan rasa keadilan yang hakiki.

Kegiatan penelitian ini diarahkan untuk mempelajari isi dan tatanan hukum positif khusunya hukum perbankan secara kongkrit serta menggali asas-asas hukum serta konsep-konsep hukum yang ada dalam kehidupan masyarakat dalam rangka mewujudkan rasa kepastian hukum. Sehubunga hal tersebut diperlukan interpretasi terhadap kaidahkaidah hukum yang telah berlaku.Adapun tehnik analisis bahan hukum yaitu Pertama, Bahan Primer, dianalisis dengan menggunakan teori Al-Maslahah Al-Mursalah, teori Perundang-undangan, dan teori Sumber hukum sebagai pisau analisis dalam mencari dan mengkaji terkait rumusan masalah. Kedua, Bahan Sekunder dianalisis dengan data kualitatif yang berguna untuk memperkuat kajian dari perundang-undangan yang berdasarkan tujuan hukum yang sebenarnya. Ketiga, kamus untuk mencari pengertian secara gramatikal.

\section{Pembahasan Hasil Penelitian}

Indonesia adalah negara kepulauan terbesar didunia yang memiliki beragam Suku Bangsa, Bahasa dan Agama dengan jumlah penduduk 240 juta. Meskipun bukan Negara Islam, Indonesia merupakan negara dengan penduduk Muslim terbesar di dunia dengan jumlah penduduk beragama Islam sebanyak 88 persen, Kristen 5 persen, Katolik 3 persen, Hindu 2 persen, Budha 1 persen, dan lainya 1 persen. Semakin majunya sistem keuangan dan perbankan serta semakin meningkatnya kesejahteraan, kebutuhan masyarakat, khususnya Muslim, menyebabkan semakin besarnya kebutuhan terhadap layanan jasa perbankan yang sesuai dengan prinsip Syariah.

Perbankan Islam adalah Kitabullah tentang perbankan dan lembaga keuangan terkait (Wakalah, Hawalah, Wadiah, Murabahah, Mudharabah, Qardh, dan sebagainya). Salah satu elemen yang sangat urgen dalam diskursus dan praktik ekonomi Islam adalah problematika riba. Riba bukanlah representasi seutuhnya ekonomi Islam, tetapi posisi riba cukup dominan di dalamnya terutama jika dikaitkan dengan Perbankan Islam. Pro dan kontra hukum bunga bank telah menjadi polemik sejak lama. Seperti didokumentasikan Murtadla Muthahari (1995), bahwa Plato dalam The Law Of Plato dan Aristoteles dalam Politics, keduanya melarang praktik pinjam meminjam 
Uang dengan sistem rente,uang adalah alat untuk jual beli, danhutang merupakan out put dari proses jual beli. Sedangkan bunga adalah uang yang lahir dari uang. meminjamkan uang dengan bunga merupakan pekerjaan hina (Muthahari, 1995). Adapun yang menjadi Karakteristik Islamic Banking dalam hukum Perbankan Indonesia dapat dilihat diantaranya:

1. Universal

Sebagai konsekuensi bahwa Islam ditetapkan sebagai agama yang rahmatan lil 'alamin oleh Allah SWT., maka Syariat Islam memiliki sifat universal. Disebut memilik sifat universal karena ketentuan-ketentuan Islam (prinsip syariah) berlaku tidak terbatas pada waktu tertentu saja tidak terbatas pada tempat tertentu saja. Ketentuan-ketentuan Islam (prinsip syariah) berlaku kapan pun dan sepanjang zaman serta berlaku diseluruh dunia.

Seandainya manusia suatu saat menghuni planet lain digalaksi lain, Hukum Islam (prinsip syariah) yang tidak lain adalah hukum Allah berlaku pula disana. Namun mengingat banyak ketentuan hukum Islam yang konstektual, sehingga bahkan harus disesuaikan dengan keadaan yang telah berubah dan/atau berlainan dibandingkan dengan keadaanya ketika ketentuan tersebut diturunkan sebagai ketentuan Al-Quran atau ketika tercipta sebagai AlHadist sewaktu Rasulullah SAW masih hidup, maka hukum Islam itu menjadi tidak akan lekang oleh zaman dan keadaan. Hanya ketentuan Al-Quran yang mutlak dan tidak boleh diubah atau disesuaikan yang tidak lentur (Sjahdeini, 2014).

Syariah Islam sebagai suatu syariah yang dibawa oleh rasul terakhir, mempunyai keunikan tersendiri. Syariah ini bukan saja menyeluruh atau komprehensif, tetapi juga universal. Karakter istimewa ini diperlukan sebab tidak akan ada syariah lain yang datang untuk menyempurnakanya. Universal bermakna Syariah Islam dapat diterapkan dalam setiap waktu dan tempat sampai hari akhir nanti. Universalitas ini tampak jelas terutama pada bidang Perbankan Islam. Selain mempunyai cakupan luas dan fleksibel, Perbankan Islami tidak membeda-bedakan antara nasabah muslim dan non muslim.Perbankan Islami juga memandang bahwa berlaku untuk setiap orang tanpa memandang perbedaan kemampuan ekonomi.

2. Maslahah

Islam selain memiliki sifat universal juga memiliki sifat komprehensif. Islam memiliki sifat komprehensif karena mencakup semua dimensi atau aspek kehidupan manusia baik yang ritual (mahdhah) maupun sosial (muamalah), material dan moral, ekonomi, politik, hukum, sosial, kebudayaan, keamanan, nasional, dan internasional. Syariat Islam bersifat komprehensif adalah juga karena Islam mengatur berbagai hubungan manusia, yaitu hubungan-hubungan manusia sebagai berikut: Manusia dan Tuhan; hubungan manusia dengan tuhan disebut hablum minallah; Manusia dan manusia lainya; hubungan manusia manusia lainya disebut hablum minannas; dan Manusia dan alam.

Perintah maupun larangan dalam Islam untuk berperilaku tertentu, baik berupa melakukan sesuatu (commission) atau berdiam diri tidak melakukan sesuatu (omission), bukan tanpa maksud tertentu. Islam memerintahkan atau melarang untuk berperilaku tertentu adalah untuk menjaga atau melindungi lima hal yang dikenal sebagai maqashid asy-syariah. Kelima hal tersebut adalah sebagai berikut (Sjahdeini, 2014):

1. Hifdzu din, yaitu memelihara kebebasan beragama; Islam tidak boleh menganggu oang lain yang memiliki keyakinan lain, sebagaimana Islam berkewajiban pula untuk membela agama dan dirinya terhadap gangguan pihak lain yang memiliki keyakinan lain. 
2. Hifdzu aql, yaitu memelihara kebebasan nalar untuk berfikir dan kebebasan untuk berpendapat lain dengan orang lain

3. Hifdzu mal, yaitu memelihara/menjaga kebebasan untuk memiliki harta dan melindungi harta bendanya itu.

4. Hifdzu nafs, yaitu memelihara hak untuk hidup

5. Hifdzu nasl, yaitu memelihara hak untuk mengembangkan keturunan.

Kelima prinsip dasar tersebut merupakan pengawal Islam sebagai agama yang bersifat rahmatan lil alamin. Sebagai tujuan Islam yaitu untuk kemaslahatan bersama dan mewujudkan kesejateraan dunia maupun akhirat. Perintah syariah diarahkan menuju keperwujudan beragam tujuan untuk kesejahteraan umat manusia. Tujuan syariah ditekankan dalam banyak teks alquran dan sunnah. Kontrak (akad) atau transaksi apapun yang menghalangi salah satu sasaran tersebut tidaklah sah dalam syariah. Cukuplah jelas bahwa hak dari semua umat manusia harus dihargai dari sudut pandang dari semua transaksi. Hak-hak Allah SWT., dalam syariah juga mengacu pada semua hal yang melibatkan manfaat masyarakat secara luas. Dalam hal ini, mereka sesuai dengan hak publik dalamperaturan modern, karenanya, kontrak (akad) apapun seharusnya tidak berlawanan dengan manfaat publik secara luas (Ayub, 2009).

Studi atas tujuan-tujuan syariah sangatlah penting karena merefleksikan jiwa syariah dan membantu para ahli hukum Islam dalam menentukan larangan atau hal-hal yang diperbolehkan atas persoalan apapun berdasarkan Ijtihad dan Qiyas. Memenuhi kesejahteraan orang-orang dikehidupan dunia dan juga kehidupan akhirat. Islam memiliki pandangan positif tentang kehidupan mengingat manusia sebagai khalifah Tuhan. Jika melakukan pencermatan yang mendalam tentang konsep dari maqashid, maka akan muncul kesan bahwa nilai utama (core value) dalam setiap aspek yang disebutkan diatas adalah mashlahah (Siddiqi, 1996).

Perbankan Islam akan menjual barang yang mereka beli dengan menguntungkan, menyewakan aset dengan imbalan uang sewa, dan membagi keuntungan (atau menanggung risiko) yang dihasilkan dari investasi yang berbasiskan syirkah. Mereka akan memabantu masyarakat untuk berkembang dengan memfasilitasi investasi yang berbasiskan aset dan menyediakan modal yang berbasiskan risiko. Negara atau regulator akan dituntut mengawasi fungsi mereka guna memastikan kepentingan beragam pemangku kepentingan benarbenar dilindingi. Berdasarkan kebijaksanaan dewan mereka dan dengan berkonsultasi dengan pemangku kepentingan, mereka dapat pula ikut serta dalam aktivitas sosial dan kesejateraan, tapi hal ini tidak akan menjadi tujuan utama bisnis mereka. Kemaslahatan didalam Perbankan Islami yang berarti bermanfaat dan membawa kebaikan bagi seluruh aspek kehidupan, baik dari nasabah maupun Shahibul Mal.

3. Variatif

Diantara apa yang dikeluhkan terhadap Perbankan Islam adalah dikarenakan sedikitnya produk yang bisa mengakomodasikan kebutuhan masyarakat, berbeda dengan apa yang dimiliki perbankan konvensional yang tampak aktif dengan merekayasa produknya. Hal Ini disebabkan oleh bermacam-macam kendala, seperti masalah regulasi, perlakuan yang cenderung menyamaratakan semua bank, sumber daya, dan lainya. Padahal jika Perbankan Islam dibebaskan untuk mengembangkan produknya sendiri menurut teori Perbankan Islam, maka produknya akan sangat bervariatif mengikuti produk-produk hukum Islam. Disamping itu pula, sifat produk Perbankan Islam yang tidak mengenal bunga, berdampak pada stabilisasi nilai mata uang, karena Perbankan Islam tidak bisa dipisahkan dari transaksi riil. 
Jika pra syarat tersebut diatas terpenuhi, maka tinggal usaha Perbankan Islam untuk mengolah dan membuat terobosan produk agar bisa kompetitif dengan produk lainnya didunia perbankan, serta diadaptasikan dengan teknologi yang sedang dan akan berkembang.Produk Perbankan Islam bersifat istimewa dikarenakan apa yang ada di bank konvensional dapat di laksanakan sepanjang tidak melangar Syariat Islam di tambah produk sewa dan gadai yang tidak dapat di laksanakan pada bank konvensional.

Produk didalam Perbankan Islami sangat bervariasi mulai dari tabungan haji dan umrah, tabungan umum, giro, deposito, pembiayaan yang berbasis bagi hasil, jual-beli dan sewa, sampai kepada produk jasa kustodian, jasa transfer, dan jasa pembayaran (debet card, syariah charge). Hal itulah yang mendasari produk-produk Perbankan Islami sekarang menjadi produk unggulan dibanding produk yang ada di perbankan konvensional.

4. Keadilan dan Transaksi yang Jujur

Prinsip paling utama yang mengatur semua aktivitas perekonomian adalah keadilan yang berarti transaksi yang adil terhadap semua pihak dan tetap menjaga keseimbangan. Keadilan menjaga langit dan bumi pada tempat yang sewajarnya serta juga merupakan kekuatan yang mempererat beragam segmen dimasyarakat. Kitab suci al-quran memaparkan: “...dan janganlah kebencianmu terhadap suatu kaum mendorong kamu untuk berlaku tidak adil. Berlaku adillah. Karena (adil) itu lebih dekat kepada taqwa..." (QS. Al-Maaidah, [5]). Penekanan hal ini, dijelaskan lebih lanjut dalam Al-Quran: “Wahai orang-orang yang beriman! Jadilah kamu penegak keadilan, menjadi saksi karena Allah" (QS. AnNisa, [4]). Hal ini memperjelas bahwa siapapun yang percaya kepada Tuhan harus berlaku adil terhadap semua orang bahkan terhadap musuhmusuhnya.
Islam, dengan demikian, mennutut hak dan kewajiban seseorang tidak lebih besar atau lebih kecil dibandingkan hak dan kewajiban orang lain. Peraturan bisnis sama-sama bisa diterapkan ke semua orang. Tidak ada orang yang bisa mengambil hak milik orang lain dengan cara yang tidak benar. Dalam pidatonya yang terkenal pada perjalanan hajinya yang terakhir. Nabi Muhammad SAW., menerangkan bahwa hak umat manusia tidak dapat diganggu gugat dalam tiga kategori, yakni perorangan, harta benda, dan kehormatan. Awal-awal masa Islam hingga abad pertengahan, banyak penekanan yang diberikan pada pembangunan karakter masyarakat guna memastikan keadilan, kejujuran diantara satu dan yang lain, serta hasil berupa keharmonisan dalam masyarakat. Banyak peristiwa keadilan dan keseimbangan yang luar biasa dalam perkembangan masyarakat manusia (Ayub, 2009).

Keadilan dalam Islamic Banking memberikan sesuatu hanya kepada yang berhak serta memperlakukan sesuatu sesuai dengan posisinya dan melaran adanya unsur maysir (unsur spekulasi atau untung-untungan), gharar (ketidakjelasan), haram, riba.

5. Transparan

Islamic bankingdan institusi finansial dituntut untuk mengadopsi transparansi, disklosur, Serta dokumentasi lebih jauh dibandingkan bank konvensional. Kurangnya transparansi dalam transaksi Murabahah, dimana bank Islam (Islamic Banking) dituntut untuk menyediakan semua detail dari biaya/harga dan cara pembayaran, bisa menjadikan transaksinya tidak sesuai dengan ajaran syariah. Kitab suci Al-Quran memerintahkan kita menulis dan menjadi saksi dalam semua transaksi yang melibatkan kredit dalam bentuk apapun. Hal serupa juga diungkapkan oleh Nabi Muhammad SAW., bahwa beliau mendukung disklosur atas semua karakteristik barang yang diperda- 
gangkan dan lingkungan yang kompetitif tempat orang-orangnya mendapatkan informasi memadai mengenai barang dan harganya di pasar.

Standar disklosur dari bank Islam (Islamic Banking) sangatlah ketat karena peranya tidak hanya terbatas pada pihak pasif yang memberikan pembiayaan yang hanya memperhatikan pembayaran bunga dan pelunasan utang. Mode-mode pembiayaan keuangan/Perbankan Islam digunakan untuk membiayai aset fisik tertentu seperti permesinan, persediaan, dan perlengkapan. Oleh sebab itu, nasabah keuangan/Perbankan Islam harus memiliki bisnis yang bermanfaat secara sosial,menciptakan kekayaan riil, dan menamabah nilai terhadap perekonomian dibandingkan dengan hanya mendatangkan keuntungan dari transaksi anti sosial atau transaksi yang hanya sebatas kertas. Sebuah PerbankanIslam (Islamic Banking) adalah rekanan dalam berdagang dan harus memperhatikan dirinya dengan sifat alamiah bisnis serta posisi profitabilitas nasabah, guna menghindari risiko kerugian dan reputasi, PerbankanIslam (Islamic Banking) harus lebih waspada terhadap nasabahnya. Oleh karena itulah, diyakini bahwa Perbankan Islam (Islamic Banking) lebih kecil Kemungkinanya untuk terlibat dalam aktifitas ilegal seperti pencucian uang dan pembiayaan terorismejika dibandingkan dengan bank konvensional (Ayub, 2009).

6. Seimbang

Tidak dapat dipungkiri lagi bahwa sektor UMKM (usaha mikro, kecil, dan menengah) adalah sektor yang sangat penting bagi perekonomian di Indonesia. Berdasarkan historis perjalananan perekonomian Indonesia ini, sektor UMKM adalah sektor yang dapat menyumbang banyak kontribusi didalam memajukan dan mengenalkan perekonomian di Indonesia. Hal ini bisa dibuktikan dari besarnya kontribusi sektor UMKM terhadap
PDB (produk domestik bruto) Indonesia dalam beberapa kurun tahun terakhir. Ketika terjadi krisis ekonomi yang melanda bangsa Indonesia pada tahun 1998, sektor UMKM-lah yang tetap dan mampu bertahan memberikan kontribusi yang positif bagi perekonomian di Indonesia.

Mengembangkan sektor keuangan melalui akitfitas Perbankan Islam yang mencangkup pengembangan sektor riil dan UMKM (Usaha Mikro, Kecil, dan Menengah). di saat sektor lain mayoritas mengalami pertumbuhan yang lemah. Di samping mampu memberikan kontribusi yang kuat atau positif dalam segi PDB Indonesia, sektor UMKM juga merupakan sektor yang mampu dan dapat menyerap tenaga kerja terbesar di Negaraini.

Di samping dukungan dari pemerintah, sektor UMKM juga membutuhkan permodalan untuk memajukan usahanya. Bantuan finansial mampu didukung oleh lembaga keuangan oleh bank melalui fasilitas kredit ataupun pembiayaannya sehingga dengan bantuan kredit atau pembiayaan tersebut, para produsen dalam sektor UMKM mampu mengembangkan usaha yang digelutinya dengan lebih cepat. Bantuan permodalan yang paling utamaguna memberikan tambahan untuk sektor UMKM adalah melalui bantuan keuangan mikro (microfinance) melalui bantuan permodalan dan pembiayaan dari Bank Perkreditan Rakyat (BPR) atau Bank Pembiayaan Rakyat Syariah (BPRS) maupun dari lembaga keuangan mikro yang dibuat oleh Bank Umum Syariah.

7. Fasilitas

Dewasa ini dunia perbankan mempunyai fungsi yang cukup penting dalam kehidupan keuangan manusia sehari-hari khususnya bagi mereka yang melakukan transaksi demi kelancaran bisnisnya. Dunia bisnis apapun akan sangat terbantu dan mudah dengan adanya berbagai macam layanan perbankan yang telah disediakan oleh lembaga keuangan se- 
perti bank pada umunya. Setiap bank kemungkinan besar akan mempunyai layanan bank yang berbeda dengan bank lain. Namun, terdapat layanan umum bank yang harus dimiliki oleh setiap bank. Salah satu layanan yang pada umumnya wajib dimilki oleh setiap bank adalah adanya layanan call center/ layanan pengaduan Konsumen. Layanan pengaduan Konsumen ini berfungsi untuk memberikan informasi seputar saldo para nasabah bank dan menerima komplain dari para nasabah. bank juga akan memberikan suatu rincian transaksi nasabah melalui layananpengaduanKonsumen ini jika diperlukan.

Fasilitas. Penerimaan dan penyaluran zakat, infak, sedekah, wakaf, dana kebajikan (qard), memiliki fasilitas Ajungan Tunai Mandiri (ATM), mobile banking, internet banking dan interkoneksi antarbank syariah. Layanan umum Perbankan Islam adalah adanya service ATM dimana ATM akan memberikan kemudahan transaksi bagi nasabah. Setiap nasabah dapat melakukan pengambilan uang secara tunai dengan menggunakan layanan bank ini. Fasilitas mesin ATM akan disebar luaskan seluruh wilayah Indonesia. Oleh karena itu, para nasabah akan dengan mudah dapat menggunakan ATM. sekarang ini nasabah diberi kemudahan lagi yaitu mereka bisa melakukan transaksi pembayaran beberapa tagihan seperti tagihan listrik, telepon, dan juga pembayaran pajak, dan serta lainya. Layanan Perbankan Islam yang terakhir adalah adanya kantor cabang bank di beberapa wilayah. Dengan adanya kantor cabang di berbagai wilayah akan mempermudah para nasabah untuk melalukan with drawal dan deposito.

Dengan demikian memanfaatkan fasilitas keuangan yang ditawarkan oleh Perbankan Islam adalah pilihan yang tepat bagi setiap umat muslim di Indonesia. Berbagai hal atau sesuatu yang dilarang dalam agama Islam bisa dihindari dengan maksimal bila layanan Perbankan Islam dari bank berbasis syariah segera dimanfaatkan. Dengan demikian, aktivitas perbankan dan seluruh fasilitas keuangan yang diterapkan di Perbankan Islam sudah disesuaikan dengan baik berdasarkan nilainilai agama beserta aturanya. yang mampu mengatur berbagai macam urusan keuangan Islam dan juga perbankan yang baik, halal dan bermanfaat tanpa ada unsur riba dan semacamnya.

\section{Simpulan}

Berdasarkan pemaparan tersebut bahwa beroperasinya Perbankan Islammempunyai karakteristik utama yang menjadi prinsip sistem Perbankan Islam di Indonesia yaitu bersifat universal memandang bahwa Perbankan Islam berlaku untuk setiap orang tanpa memandang perbedaan agama dan kemampuan ekonomi. Variatif bahwa produk bervariasi mulai dari tabungan haji dan umrah, tabungan umum, giro, deposito, pembiayaan yang berbasis bagi hasil, jual beli dan sewa. Fasilitatif bahwa penerimaan dan penyaluran zakat, infak, sedekah, wakaf dana kebajikan memiliki fasilitas ATM, mobile banking, internet banking dan interkoneksi antar Perbankan Islam.

Adil bahwa Perbankan Islam memberikan sesuatu hanya kepada yang berhak serta memperlakukan sesuatu sesuai dengan porsinya. Maslahah Perbankan Islam bermanfaat dan membawa kebajikan bagi seluruh aspek kehidupan. Transparan dalam kegiatanya Perbankan Islam sangat terbuka bagi seluruh masyarakat. serta transaksi yang jujur dalam menjalankan suatu kontrak/akad. Melihat beberapa karakteristik ini, kita bisa memahami bahwa Perbankan Islam di Indonesia sudah memiliki landasan awal yang kokoh sebagai implementasi dari Falsafah Ekonomi Syariah. 


\section{Saran}

Perbankan Islam di Indonesia yang keberadaanya harus benar-benar dimanfaatkan dan dilaksanakan oleh seluruh umat Islam di Indonesia secara lengkap dan utuh, dalam rangka meningkatkan keimanan dan ketaqwaan kepada Allah SWT, Rasul-Nya dan kitab Al-Quran dan AsSunnah. Sehingga umat Islam di Indonesia maupun di dunia tidak akan terjerumus pada perbuatan Riba yang sangat dilarang Allah SWT.

Kesesuaian bisnis dan transaksi dengan prinsip Islam sangat penting untuk memastikan integritas dan kredibilitas industri Perbankan Islam. Oleh karena, itu Perbankan Islam harus memastikan apapun yang mereka tawarkan harus telah sesuai dengan ajaran syariah. dan jarangnya sumber daya manusia yang terlatih dalam hal pengembangan industri Perbankan Islam, maka dari itu, perlunya pelatihan dan pendidikan Perbankan Islam dengan berkolaborasi bersama akademik dan institusi finansial Islam ternama, misalnya: cendekiawan syariah, komunitas bisnis syariah dll.Pemerintah harus mendukung penuh dalam pengembangan Perbankan Islam di Indonesia agar tercapainya tujuan yang diidam-idamkan masyarakat untuk menggunakan perbankan yang bebas dari riba.

\section{DAFTAR PUSTAKA}

Abdullah,M. Noman. 2003.Imperatives of Financial Innovations For Islamic Banks' in International. J. of Islamic Financial Services,Islamic Finance.

Ayub, Muhammad.2009.Understanding Islamic Finance. Gramedia Pustaka Utama. Jakarta.

Fatwa Majelis Ulama Indonesia Nomor 1 Tahun 2004 tentang Pelarangan Bunga Sebagai Salah
Satu Bentuk Riba. (Fatwa Majelis Ulama Indonesia Nomor 1 Tahun 2004). Jakarta.

Muthahari, Murtadla. 1995. Asuransi dan Riba. Pustaka Hidayah. Bandung.

Saeed, Abdullah. 1996.Islamic Banking And Interest: A Study of The Prohibition of Riba and its Contemporary Interpretation. J. Briil. LeidenNew York-Koln.

Saudi, Gazette. 2015. Aset Keuangan Islam www.saudigazette.com.sa/index.cfm. diakses tanggal 8 Januari 2017.

Siddiqi, M. Nejatullah. 1996. Role of The State in The Economy an Islamic Perspective.Islamic Foundation. Markfield.

Sjahdeini, Sutan Remy. 2014.Perbankan Syariah Produk-Produk dan Aspek-Aspek Hukumnya. Kencana Prenadamedia Group. Jakarta.

Triyanta, Agus. 2016. Hukum Perbankan Syariah Regulasi, Implementasi dan Formulasi Kepatuhanya Terhadap Prinsip-Prinsip Islam. Setara Press. Malang.

Undang-Undang Dasar Republik Indonesia Tahun 1945. Jakarta.

Undang-Undang Republik Indonesia Nomor 10 Tahun 1998 tentang Perubahan Atas UndangUndang Republik Indonesia Nomor 7 Tahun 1992 Tentang Perbankan. Jakarta.

Undang-Undang Republik IndonesiaNomor21 Tahun 2008 tentang Perbankan Syariah. Jakarta. Wilson, Rodney., 1995, Islamic Banking and its Impact on The International Financial Scene.J. of International Banking Law. Accesed From Westlaw Database.

\section{How to Cite:}

Lathif, Muhammad Abdul. 2017. Karakteristik Islamic Banking dalam Hukum Perbankan Indonesia. Jurnal Cakrawala Hukum. 8 (1): 1-11. 